\title{
ANALYSIS OF TERM MEANING "COMPUTATIONAL THINKING"
}

\section{Daniel LESSNER}

Resumé: Článek představuje koncept „,computational thinking“ (CT). Tato schopnost „myslet jako informatik při řešení problémư“ si v souvislosti s výukou informatiky získává stále více pozornosti. V článku proto stručně probereme a porovnáme několik odlišných vymezení $\mathrm{CT}$, abychom mohli koncept následně srovnat $\mathrm{s}$ kategoriemi českému čtenáři bližšími, totiž s klíčovými kompetencemi a gramotnostmi.

Ve druhé polovině článku uvedená teoretická vymezení ilustrujeme množstvím př́kladů použití CT v životě i ve výuce. Koncept CT poskytuje vhodné východisko pro hledání toho, co v naší výuce „,informatiky“ zaměřené na používání technologií chybí.

\section{ANALÝZA VÝZNAMU POJMU ,COMPUTATIONAL THINKING}

Klíčová slova: computational thinking, informatické myšlení, didaktika informatiky.

Abstract: The article introduces the concept of computational thinking (CT). This ability "to think like a computer scientist while solving problems" draws more and more attention in relation to computer science education. We show and discuss a few definitions of CT. The concept can then be compared to key competences and literacies as used in Czechia.

The second half of the article illustrates the theoretical specifications with a variety of examples from both everyday life and school education. Our "computer science" classes focus on ICT user skills. CT provides a convenient starting point for the quest for what is missing in our education.

Keywords: computer science education, computational thinking. 


\section{1 Úvod}

Není nutno rozvádět, jak významně mění tvár̆ světa rychle se vyvíjející informatika. Ne každému je ovšem zřejmé, že změny nepřicházejí jen díky technickému pokroku. Ve světě proto nabývá na zvučnosti koncept computational thinking (CT).

Pro začátek nám postačí představa CT jako schopnosti ,myslet jako informatik prí řešení problémü“. Takto pojaté CT má být užitečné i mimo informatiku a snad i univerzálně, tedy pro každého.

Balením školní brašny žák projevuje informatické myšlení, předběžně načítá (nebo spíšs nakládá) do pracovního úložiště. Maminka myslí jako informatik, když zorganizuje jogurty $\mathrm{v}$ chladničce do prioritní fronty podle data spotřeby. Výběr nejrychlejší fronty $\mathrm{v}$ supermarketu vyžaduje modelování výkonnosti. Telefonní linka fungující i při výpadku proudu ukazuje redundanci a nezávislost selhání v návrhu. $\mathrm{V}$ jednoduchých situacích postačí „selský rozum“. Dále v článku popíšeme i složitější situace, v nichž se už uplatní schopnost použít znalosti z informatiky.

CT je pokusem uchopit právě „to ono“, co při řešení (i neinformatických) problémů odlišuje informatiky a neinformatiky, a co se často intuitivně snažíme při výuce v žácích probudit a rozvíjet.

Takový koncept je v souladu s převažujícím vývojem názorů na informatiku $\mathrm{v}$ primárním a sekundárním vzdělávání ve světě. Výuka informatiky tak už nesměřuje jen ke zvládnutí užívání ICT pro běžný život a případná výuka programování neslouží primárně k ovládnutí syntaxe jazyka a tvorbě programů. Cílem je obdoba kultivace myšlení, ke které má docházet např. ve výuce matematiky (vedle např. tréninku početních dovedností).

$\mathrm{V}$ češtině je ovšem o CT minimum dostupných informací. V tomto článku jej proto blíže představíme českým zájemcům.

$\mathrm{Na}$ stručný historický úvod navážeme ukázkou a srovnáním několika nejdůležitějších vymezení CT od různých autorů. Dále stručně prozkoumáme vztah CT s klíčovými kompetencemi a gramotnostmi užívanými $\mathrm{v}$ českém prostředí ${ }^{1}$. Tuto teoretickou diskusi doplníme ukázkami konkrétních situací a náměty použitelnými ve výuce.

1 Někteří čtenáři by možná čekali srovnání CT S Rámcovými vzdělávacími programy jako takovými, tedy včetně vzdělávacích oblastí, průřezových témat atd. Souvislosti s CT bychom přirozeně hledali především v oblastech matematika a informatika. I rychlý pohled ale ukáže, že není co zkoumat. Odhlédneme-li od klíčových kompetencí, RVP ZV rozvoj CT nezahrnuje. To není žádným překvapením, když si uvědomíme, že nezahrnuje ani výuku informatiky. Pro srovnání doporučujeme slovenský Štátny vzdelávací program. 
Smyslem př́spěvku je seznámit čtenáře s konceptem CT a prozkoumat, jak může CT prospět výuce informatiky na našich školách. Přirozeně totiž vyvstává otázka, jestli je CT jen jiný úhel pohledu na to, co už máme obsaženo např. právě v klíčových kompetencích, nebo jestli přináší i něco nového a má smysl se jím dále zabývat - a snad najít i vhodný český překlad.

\section{Původ CT}

První použití sousloví computational thinking je prripisováno Seymouru Papertovi, autorovi původní verze programovacího jazyka LOGO, určeného ke konstruktivistickému vzdělávání $[1,2]$, a jedné z vưdčích postav iniciativy One Laptop per Child. V článku [3] Papert diskutuje, jaké změny přináší možnost využití počítačů do výuky matematiky, pojem CT nicméně dále nerozvíjí.

Současný zájem o CT spustila Jeanette Wing z Carnegie Mellon University (CMU) až článkem [4]. Představila $\mathrm{v}$ něm vizi $\mathrm{CT}$ jako schopnosti podobně základní, jako je čtení, psaní a počítání, a především podobně potřebné. Wing se primárně nesnaží o rozšíření řad uchazečů o studium informatiky. Snaží se ukázat, že porozumění informatice se hodí jak profesionálům napříč obory, tak při řešení běžných každodenních problémů - obojí pochopitelně na odpovídající úrovni složitosti.

Článek původně nebyl určen vzdělavatelům, ti si nicméně všimli, že by CT mohlo pomoci lépe uchopit vzdělávací cíle a aktivity $\mathrm{v}$ souvislosti $\mathrm{s}$ informatikou. Pojmenovává totiž důležitou (a obtížně uchopitelnou) stránku výuky: nikoliv použití technologií, nikoliv dovednosti IT profesionálů, nýbrž způsob přemýšlení, který si díky informatice můžeme osvojit.

Wing do CT řadí širokou škálu myšlenkových nástrojů. $\mathrm{Na}$ jedné straně stojí samozřejmé rozložení problému nebo jeho převedení na jiný. Na druhé straně potom napřr. i vyhýbání se uváznutí (deadlocku) v distribuovaných systémech, resp. skutečných situacích, které jimi lze modelovat.

Uplatnění CT má podle Wing umožnit lepší řešení starých (již nějak vyřrešených) problémů a také řešení problémů, kterým by jinak bylo nutno se vyhnout, nebo by na ně jako na problémy $\mathrm{k}$ vyřešení vůbec nebylo nahlíženo.

\section{Vymezení CT}

Definovat CT je podobně záludné, jako definovat klíčové kompetence či gramotnosti. Výsledky jsou často bud' neurčité a obtížně použitelné pro samotnou výuku, nebo sice dostatečně konkrétní, ale tím pádem dlouhé a pravděpodobně přiliš úzké. $V$ této části uvedeme několik takových pokusů o vyme- 
zení CT. Dosud totiž nebyla nalezena shoda na tom, jak CT definovat a strukturovat.

Jako první se podívejme na definici Jeanette Wing. V původním vizionářském a tedy poměrně neurčitém článku žádnou nedává, místo ní popisuje následující vlastnosti. CT je dovednost základní, tedy nutná pro plnohodnotné fungování v moderní společnosti. Jde o způsob myšlení lidí, nikoliv strojů, CT není mechanické. CT kombinuje a doplňuje matematické a technické myšlení. Používané modely jsou matematické (jako v každé vědě), jsou ale omezené konstrukčními možnostmi strojů. Z druhé strany, informatika je podobná technice, protože produkuje nástroje interagující s fyzickým světem. Vytváří si ovšem také světy vlastní, fyzikou neomezené. Už v původním článku autorka uvedla pozoruhodný rys $\mathrm{CT}$, který se $\mathrm{v}$ různých obměnách objevuje i v dalších definicích: CT samozřjejmě zahrnuje konceptualizaci, vyžaduje ovšem uvažování na několika úrovních abstrakce zároveň.

Až později jsme se dočkali definice od autorky v [5, 6]:

CT jsou myšlenkové postupy zapojené při takovém formulování problémi̊ a jejich řešení, které umožní tato řěsení efektivně provést agentem zpracovávajicím informace.

Zmíněným agentem může být jak stroj, tak člověk. CT obecně má zahrnovat schopnosti
- pochopit, které aspekty problému jsou řešitelné strojově;

- vyhodnotit shodu mezi informatickými prostředky a problémem;

- porozumět možnostem a omezením informatických prostředků;

- použít informatické prostředky novým způsobem či v nové situaci (nebo prostředky přizpůsobit);

- použít informatické strategie v jakékoliv oblasti.

Informatickým prostředkem se zde rozumí jak technické nástroje, tak abstraktní postupy a teoretické výsledky.

Uvedený popis se vztahuje na každého, autorka dále uvádí rožsíření pro vědce, techniky a další profesionály. To se týká především řešení problémů s pomocí velkých dat a použití informatické terminologie. Připomeňme, že definice $\mathrm{J}$. Wing má fungovat obecně, není určena do školství jako vzdělávací cíl. Určení obsahu a dovedností vhodných pro různé stupně vzdělávání je třeba hledat jinde.

Jedna z konkrétnějších a velmi používaných definic pochází ze spolupráce International Society for Technology in Education (ISTE) a Computer Science Teachers Association (CSTA) [7]. Téměř totožná definice se objevuje $\mathrm{v}$ [8]. 
CT je postup řešení problému, který zahrnuje mimo jiné následujicí charakteristiky:

- Formulovat problémy způsobem, který umožňuje jejich strojové ř rěení

- Logicky usporádávat a zkoumat data

- Reprezentovat data prostřednictvím abstrakcí, jako jsou modely a simulace

- Automatizovat řešení pomocí algoritmického myšlení (jako posloupnost krokü)

- Odhalit, prozkoumat a provést možná řěsení $s$ cílem odhalit nejúčinnější kombinaci činností a zdroju

- Zobecňovat a přenášet tento postup řšsení problému do nejrůznéjších dalších oblastí

Tyto dovednosti jsou podpořeny předpoklady a postoji, které jsou taktéž nezbytnou součástí CT:

- Sebejistota tváří v tvář složitosti

- Vytrvalost při řěsení obtǐzného problému

- Snášení nejednoznačnosti

- Schopnost vypořádat se sotevrenými problémy

- Schopnost dorozumět se a spolupracovat $s$ ostatními pri dosahování společného cíle

Oblíbenost této definice vyplývá z její struktury. Charakteristika CT je zde dostatečně konkrétní k tomu, aby umožňovala plánování výukových aktivit. Mezi ostatními vyniká tato definice také zahrnutím postojové části. Ta mimochodem dále zpřesňuje, o jaké problémy se v souvislosti s CT jedná, což je opět velmi užitečné při plánování výuky. Navíc si můžeme všimnout, že uvedené postoje u nás cíleně téměř nerozvíjíme.

\section{Britská Královská společnost} formulovala svůj vlastní přístup:

$C T$ je postup rozpoznávání informatických aspektů světa kolem nás a využití informatických prostředků $k$ porozuměni a uvažování o prirozených $i$ umélých systémech a procesech [9].

Definice je na velmi vysoké úrovni, přitom je ale poměrně srozumitelná. Neopírá se príliš o termíny $\mathrm{z}$ informatiky, naopak zdůrazňuje roli CT v životě člověka a roli informatiky jako prrírodní vědy pro zkoumání světa. Ve svojí obecnosti je tedy $\mathrm{v}$ jistém protikladu k ostatním definicím. V pozadí lze spatřit podobnou myšlenkovou konstrukci, s jakou se setkáváme $\mathrm{v}$ definici matematické gramotnos$t i$, tedy (zkráceně) dostatečnému porozumění matematice spolu se schopností jej využít $\mathrm{v}$ běžném životě (přesněji viz dále).

Následující vymezení nejsou prímo zaštítěna vědeckou prací, právě proto ale vhodně dokreslují celkový obrázek. Vlastní web o CT ve vzdělávání provozuje společnost Google [10]. Kromě množství prííkladů uvádí i svou definici: 
CT zahrnuje sadu technik a dovedností $k$ rešení problémi̊, které při psaní běžně použivaných aplikací (vyhledávání, email, mapy), používají softwaroví inženýrí. CT je nicméně využitelné téměr $v$ jakémkoliv predmětu. Součástí CT jsou zejména:

- rozklad problému,

- rozpoznávání vzorĩ (např. $v$ grafech na burze, ale $i$ v procesech),

- zobecňování vzorĩ (tedy vytvárení abstraktních modelì),

- navrhování algoritmů.

Toto pojetí CT je nepochybně přízemnější. Zdá se, že čerpá především z ,̌remesla“ kodérů a „,vědu“ informatiků zcela pomíjí. Patrně ale není na místě $\mathrm{v}$ tom hledat záměr ,nemáme v Googlu dost programátorů“. Je nutno mít na paměti poněkud posunuté anglické významy „computer science“ a ,computing “ vưči české informatice. Google na svých stránkách uvádí značné množství prríkladů výukových aktivit, které jsou programování velmi vzdálené (viz níže). Navíc uvedené čtyři základní složky nejsou nikterak triviální. Tvoří přitom logický obecný rámec řešení problémů.

Další odlišností uvedeného vymezení CT je výslovné zahrnutí rozpoznávání vzorů jako jedné z hlavních složek CT. To do konceptu velmi přirozeně zapadá a vede ke vzniku mnoha neobvyklých a zajímavých výukových aktivit.

Posledním kamínkem mozaiky vymezení pochází z webu Computer Science For Fun [11], který provozuje Queen Mary University of London. CT je podle jeho autoru sada rozličných dovedností, které souvisí s rešením problému a vyplývají ze zkoumání povahy zpracováni informace. Zahrnuje jak dovednosti rozvíjené většinou předmétů (jako tvořivost, schopnost vysvètlování a týmové práce), tak $i$ několik velmi specifických dovedností řešení problémů, jako schopnost logického, algoritmického a rekurzivního myšlení.

Informatika má tyto rozličné dovednosti jedinečným způsobem spojovat. CT potom autoři rozkládají na další druhy myšlení: logické, algoritmické, efektivní, vědecké, a inovativní. Celkově ale toto vymezení trpí právě odkazy na další koncepty, které již ale nejsou definované.

$\mathrm{Na}$ závěr této části vymezení krátce srovnejme. Co se týče rozdílů, jsme svědky různé úrovně konkrétnosti, různě silného sepětí $\mathrm{CT}$ a programování či CT a teoretické informatiky.

Hledání společných znaků pak odhalí především zaměření na řešení široké škály problémů, použití abstrakce (často dokonce na několika úrovních zároveň), důraz na znalost a tvůrčí použití principů informatiky namísto znalostí uživa- 
telských, přesahy do dalších oblastí (logika, vyjadřování, práce v týmu, ostatní prrírodní vědy...) a snahu o efektivitu výsledných řešení (vč. posouzení vhodnosti strojového řešení a jeho mezí). To vše má být přitom návazné i na problémy každodenního života, a CT tak má být součástí všeobecného vzdělání.

Snad je tedy nyní konkrétněji patrné, co je myšleno spojením „myslet jako informatik“. Šíre uvedených charakteristik CT by již měla stačit $\mathrm{k}$ tomu, aby si o CT čtenář udělal poměrně jasnou představu. Kromě toho si může vybrat, které pojetí nejlépe odpovídá potřebám jeho žáků a výuky (popríipadě různé př́istupy zkombinovat.

\section{Klíčové kompetence a CT}

Čeští učitelé se v současnosti potýkají s dlouhou řadou kompetencí, gramotností a dalších poměrně abstraktních konceptů. Je proto na místě vyjasnit, v jakém vztahu k nim je CT. Přirozeně totiž vyvstává otázka, jestli není CT jen jiný úhel pohledu na to, co už máme obsaženo např. právě v klíčových kompetencích, tudíž to ve výuce rozvíjíme a koncept CT nepotřebujeme.

Výkladů pojmu klíčové kompetence najdeme $\mathrm{v}$ odborné literatuře více [12], vzhledem k účelu článku jsme se rozhodli přidržet výkladu z Rámcového vzdělávacího pro- gramu pro základní vzdělávání ${ }^{2}$ a souvisejících dokumentů.

Jako první se přirozeně zaměříme na kompetenci $k$ řešení problé$m$ mi (KŘP). Podle očekávání najdeme s CT značný překryv. Popis KŘP využívá slova a formulace jako promyšlený systematický postup, rozhodování, kritické myšlení, předvídání neočekávaných situací, práce s informacemi, diagnostika chyb, překonávání neúspěchu a dokonce i zobecňování výsledných řešení.

Přitom není informatika nikde zmíněna výslovně. To je poněkud škoda s ohledem na to, že matematika a logika výslovně uvedeny jsou. Přitom je to právě informatika, která poskytuje nástroje pro mnohé součástí KŘP, vč. výše uvedených.

Vztah KŘP a informatiky je podobný vztahu Ǩ̌P a matematiky.

2 Nutnost výběru je dána rozdíly a rozpory mezi jednotlivými dokumenty. RVP G nahrazuje kompetenci pracovní z RVP ZV kompetencí k podnikavosti. RVP S se pak liší ještě výrazněji, když mezi klíčové kompetence řadí i kompetence využívat prostředky informačních a komunikačních technologií a pracovat $\mathrm{s}$ informacemi a kompetence matematické. To je podstatné s ohledem na to, že CT je na rozdíl od obecných klíčových kompetencí na základní škole oborové, navázané na obsah informatických předmětů. V dalším se proto omezíme na klíčové kompetence základní školy, které se týkají největšího počtu žáků. 
Zvládnutí informatiky či matematiky jistě není postačující podmínkou vysoké úrovně KŘP. Je ale jednoznačně podmínkou nutnou. Čtemeli specifikaci KŘP a rozumíme při tom možnostem využití informatiky pro řešení problémů, je souvislost zcela zřejmá. Je však poněkud zarážející, že popis nepoužívá přiléhavou informatickou terminologii. Důsledkem je, že většina uživatelů popisu KŘP souvislost s CT neuvidí, není to totiž zvykem.

Je zároveň nutno dodat, že KŘP ve skutečnosti CT důsledně nepokrývá. V popisu KŘP nenalezneme nástroje jako modely či abstrakce (což je samo o sobě zvláštní), ani náznaky preference strojového, čili algoritmického řešení. Podobně chybí jasné hodnocení efektivity různých řešení.

Tyto skutečnosti samozřejmě nic nemění na tom, že KŘP je patrně nejsilnějším pojítkem CT a RVP a že výuka informatiky pojaté jako rozvoj CT může významně posilovat KŘP.

Celkem logicky a očekávaně nalezneme souvislosti CT s kompetencemi $k$ učení a pracovní. $\mathrm{V}$ příslušných popisech uváděné plánování, provádění a hodnocení učebních i pracovních postupů přímo souvisí $\mathrm{s}$ algoritmickou stránkou CT.

Neměli bychom ovšem přehlédnout kompetenci komunikativní (KK). Komunikace je ve velmi úzkém vztahu s pojmem informace, na kterém informatika (a tím i CT) stojí. Práce $s$ informací je koneckonců součástí KK (byt' bez ohledu na otázky kódování či efektivity).

Součástí CT je i schopnost používat rozličné formální jazyky, at' už pro přesnou komunikaci s lidmi, nebo pro komunikaci př́mo se stroji. Tento zásadní aspekt ovšem KK zcela pomíjí (kromě dále nerozpracované zmínky o symbolických prostřredcích).

KK je celá vystavěna kolem mezilidské komunikace přirozeným jazykem. Dokonce i část věnovaná (uživatelskému) použití ICT předpokládá především komunikaci mezi lidmi. Přitom mnoho zákonitostí funguje $\mathrm{v}$ obou oblastech stejně právě proto, že jde o výměnu informací, bez ohledu na to, jestli některá strana komunikace žije.

Celkově lze konstatovat, že klíčové kompetence pokrývají pouze základy CT. Na druhé straně se CT jeví jako vhodný prostředek $\mathrm{k}$ jejich rozvoji. Je v pořádku, že se specifikace jednotlivých kompetencí na informatiku (prrípadně CT) přímo neodkazují, jsou koneckonců jako nadoborové zamýšleny. Je proto ovšem třeba věnovat zvláštní pozornost při interpretaci popisů, abychom na př́slušné součásti $\mathrm{CT}$ nezapomínali.

\section{Gramotnosti a CT}

Podívejme se dále krátce na vztah CT a některých gramotností. RVP s nimi sice přímo nepracují, 
přesto se nimi ve školství setkáváme [13]. Jako nejbližší CT se může jevit ICT gramotnost. Ta se ovšem zaměřuje především na použití ICT. Sice do ní spadá i zpracování informací, ale zdaleka ne tak pokročilé, jaké očekáváme v CT. Zjednodušeně lze říci, že se CT a ICT gramotnost překrývají do té míry, do jaké je třeba pro $\mathrm{CT}$ skutečně využít techniku.

Mnohem zajímavější (a bližší) je vztah CT k matematické gramotnosti. Připomeňme definici [13]:

Matematická gramotnost je schopnost jedince poznat a pochopit roli, kterou hraje matematika ve světě, dělat dobře podložené úsudky a proniknout do matematiky tak, aby splňovala jeho životní potřeby jako tvořivého, zainteresovaného a přmýšlivého občana. Záměnou několika slov se můžeme dostat překvapivě blízko CT. Totéž platí i pro podrobný popis složek matematické gramotnosti.

Na místě je proto otázka, kde leží hranice matematické gramotnosti a CT. Přeložíme-li si doslovně anglický výraz computational, nejde o velké překvapení. Hranice je tedy daná prakticky tím, kde chápeme hranici mezi (školskou) matematikou a informatikou. V kontextu vzdělávání lze zjednodušeně říci, že se matematika soustředí spíše na zadání a správný výsledek, kdežto informatika se soustředí spíše na samotný proces hledání toho výsledku a jeho zobecnění pro celou třídu problémů. Opět zjednodušeně, $v$ matematice algoritmy používáme, zatímco v informatice je hledáme a zkoumáme.

Odtud se pak obě vědy rozchází a začínají řešit odlišné druhy otázek. Jak už bylo uvedeno, informatika se omezuje na fyzicky realizovatelné a automatizovatelné modely. Navíc je žádoucí, aby realizace modelů byla efektivní.

Uvedené rozdíly snadno nahlédneme např. z obsahu učebnic, z typických úloh a dalších učebních aktivit a $\mathrm{z}$ hodnocených dovedností.

CT se tedy odlišuje zaměřením (efektivita a algoritmičnost řešení) a tím pádem někdy pokročilejším a abstraktnějším obsahem. Základní cíl, totiž úspěšné řešení problémů, ale $\mathrm{s}$ matematickou gramotností sdílí. Vzhledem k již existujícím výsledkům na poli výzkumu matematické gramotnosti by bylo zajímavé vyzkoušet podle jejího vzoru strukturovat CT (situace a kontexty, kompetence, obsah).

Za zmínku stojí také vztah CT a prírodovédné gramotnosti, vzhledem $\mathrm{k}$ tomu, že informatika je př́rodní věda. Opět se opakuje situace, že informatika, pokud čteme pozorně, vlastně zahrnuta je, ovšem nikoliv výslovně. Překryv tedy najdeme do té míry, do jaké informatika (a tím i CT) používá metody prrírodních věd uvedené $\mathrm{v}$ popisu přírodovědné gramotnosti.

Informatika (stejně jako ostatní přírodní vědy) pak používá i postu- 
py $\mathrm{v}$ popisu $\mathrm{z}$ nějakého důvodu neuvedené, především simulaci a modelování.

\section{Př́íklady ze skutečnosti}

Př́klady použití CT $\mathrm{v}$ běžném životě mohou být zcela jednoduché. Učitel tance na konci lekce vyzývá $\mathrm{k}$ přihlášení zvednutím ruky ty páry, kterým vyhovuje páteční termín závěrečného plesu, a spočte zvednuté ruce. Následně se ptá, komu vyhovuje termín sobotní. Ke zvednutí ruky ale již vyzývá jen dámy. Učitel tance právě na okamžik zauvažoval jako informatik a uvědomil si, jak zkrátit čas počítání přibližně polovinu.

Ihned se nabízí dvě námitky. První: není to matematika? Není. Matematicky jsou správně oba postupy, oba dávají správný výsledek. Při výuce matematiky se zkoumáním efektivity vyučovaných postupů zabýváme velmi zř́dkakdy.

Námitka druhá: učitel tance $\mathrm{k}$ tomuhle nemusí být informatik, stačí mu přece zdravý rozum. Ano. Tak jako $\mathrm{v}$ príípadě ostatních předmětů, i informatické problémy lze, pokud jsou jednoduché, správně vyřešit intuitivně. Odpověd' leží v kvalitě života, které chceme dosahovat. Jistě lze št'astně žít i bez CT. V principu podobně, jako lze št'astně žít bez dovednosti číst, psát a počítat.

Ukažme si nyní příklad složitější [5]. Trumpetista a informatik
Roger Dannenberg si měl stejně jako ostatní členové kapely vybrat daných asi 40 skladeb pro daný večer z neseřazené složky asi dvou set. Všichni ostatní začali postupně procházet složku a po jednom hledat a vybírat skladby. R. Dannenberg se rozhodl seřadit 200 skladeb v čase $O(N \cdot \log (N))$ a teprve potom najít hledané skladby, tedy už v čase $O(M \cdot \log (N)), \quad$ namísto $O(M \cdot N)$, tak jako ostatní ( $N$ je velikost složky, zde 200, $M$ je počet hledaných skladeb, tedy 40). Sice pořád ještě řadil, zatímco ostatní byli zpola hotovi a podivovali se jeho počínání, skončil nicméně jako první.

Poznamenejme, že v takové situaci nestačí použít heuristiku „vždycky je lepší je řadit“" nebo horní odhady složitosti. Pokud totiž nejsou vstupy přesvědčivě veliké nebo nemáme dostatečnou zkušenost, není ihned zřejmé, jestli řazení není zbytečná práce. Kdyby byl rozdíl $\mathrm{v}$ počtu skladeb $\mathrm{k}$ vyhledání a počtu skladeb ve složce výraznější, mohlo by být rychlejší prímo hledat. Dále je nutno si uvědomit, že $O(M \cdot N)$ zde nelze ztotožnit s $M \cdot N$, pravděpodobně bychom totiž náš odhad o 100 \% nadhodnotili. Trvání úkonů př́i řazení a při hledání není jednoduše zaměnitelné. Další otázkou je vhodná volba řadicího algoritmu pro dané podmínky (tedy řazení nikoliv čísel v paměti, ale papírů v lidských rukách). Pochopitelně platí, že čím 
větší problém je, tím častěji převáží (správně použitá) obecná informatická teorie nad konkrétními okolnostmi.

A nakonec si položme otázku, jestli by nebylo bývalo lepší celou úlohu obrátit naruby. Postupně projít složku a pro každou skladbu (kterou stejně vezmeme do ruky a přečteme její název) zkontrolovat, jestli se se nachází $v$ předem seřazeném seznamu 40 vybraných skladeb. Celkově potřebujeme čas $O(M \cdot \log (M))$ na seřazení seznamu a $O(N \cdot \log (M))$ na vyhledání vybraných skladeb, tedy řešení $\mathrm{v}$ tomto případě ještě lepší. Navíc je toto řešení obecně lepší častěji, tedy ve více obdobných situacích.

Tyto úvahy měly ukázat, že k efektivnímu vyřešení problému nepostačí pouhé znalosti informatiky. Je nutno jako informatik prémýšlet, znalosti použít i $\mathrm{v}$ nových situacích. Zahrnutí tradičního obsahu vědní informatiky do výuky proto samo o sobě CT nutně nerozvíjí. Výpočet očekávané složitosti Quick Sortu není rozhodující (byt' užitečný) v situaci, kdy je hlavním omezením efektivity fakt, že máme $\mathrm{k}$ dispozici pouze dvě ruce.

Podívejme se nyní na odbornější př́klady využití CT. Článek [14] uvádí množství prací, které využívají prorůstání biologie a informatiky. Pěknou ukázkou je práce [15]. Dobrovolníci zasílají nahrávky zpěvu strnadů z různých míst republiky. Nahrávky jsou pak analy- zovány a zkoumá se, jak se na různých místech liší nářečí strnadů. Bez digitální techniky by byl takový sběr dat nemyslitelný. Tisíce nahrávek jsou ovšem, navzdory dnešním možnostem, klasifikovány ručně.

$\mathrm{Na}$ závěr této části uvedeme vážnější prŕíklad [16]. Je jedním z výsledků výzkumu $\mathrm{CT}$ na $\mathrm{CMU}$. V USA každoročně smrtelně onemocní 30000 lidí, kterým by pomohla transplantace ledvin. Často se $\mathrm{v}$ rodině najde ochotný, ale nekompatibilní dárce. Proto má smysl hledat vzájemné kombinace dárců a př́ijemců tak, aby bylo zachráněno maximum životů. Řešení, které není nejlepší, nebo které je nalezeno pozdě, znamená, že zemře někdo, kdo zemřít nemusel.

Zapojení CT na straně organizátorů dárcovského systému vedlo k rozpoznání problému a posouzení jeho řešitelnosti. Následná spolupráce $s$ informatiky vedla ke kvalitativnímu zlepšení situace. To přitom nespočívá $\mathrm{v}$ nějakém technickém zařízení. Spočívá v chytřejší práci s dostupnými informacemi.

\section{CT ve výuce informatiky}

Následující př́íklady už více či méně souvisí se školní výukou. Zařazení CT do výuky informatických předmětů je poměrně přímočaré. Výuku je třeba rozš́ririt o pokročilejší informatická témata (na odpovídající úrovni obtížnosti), 
jako jsou efektivita a omezení informatiky.

Výše jsme již ovšem ukázali, že samotné zařazení př́slušných témat nestačí. Je třeba zauvažovat o tom, nakolik zahrnutá témata $\mathrm{k}$ rozvoji CT skutečně přispívají. Jiným př́ikladem může být výuka ,programování“: od výuky algoritmizace jako metody řešení problémů a způsobu nahlížení na svět je v praxi velmi snadné sklouznout k výuce programování jako zapisování programů $\mathrm{v}$ programovacím jazyce. Do diskusí o prvním programovacím jazyce se pak vkrádají nesouvisející argumenty, jako kolik procent programátorů daný jazyk využívá v práci. Koncept CT nám dává možnost si takový posun uvědomit a napravit.

Může se tak ukázat, že pokud je naším cílem seznámit žáky s ideou omezené množiny př́kazů, rozhodování, opakování, rekurzivního volání či ladění, postačí jednoduchý robotanik [17]. S nejmladšími žáky lze pracovat např. $\mathrm{v}$ prostředí šachové Figurkové školičky [18]. Odlišný typ zkušenosti nabízí výuka s pomocí robotů.

Prvotní inspiraci mimo programování jako takové lze pak hledat např. v archivu úloh dostupném na webu Bobříka informatiky. Úlohy z bobříka ukazují, jak mohou informatické principy pomoci $\mathrm{k}$ efektivnímu řešení problémů i mimo tradičně vnímanou oblast informatiky. Př́značné jsou pak některé reakce učitelů i soutěžících, které způsob přemýšlení nutný pro řešení úloh vůbec nespojují s informatikou [19].

Ucelenějším materiálem pro výuku je celosvětově úspěšná sada aktivit Computer Science Unplugged [20], která zábavným a zároveň odborně správným způsobem představuje informatiku i nejmladším dětem. Skutečnost, že předmětem zkoumání informatiky nejsou počítače, ujasňují aktivity CSU jednoduše tím, že počítače nevyužívají. Novozélandský tým stojí také za učebnicí [21], která je určena pro práci se staršími žáky. Její přínos spočívá ve zpřístupnění mnoha partií informatiky, které napřr. v Česku někdy považujeme za př́liš náročné.

\section{CT ve výuce mimo informatiku}

Pro náš článek je zajímavější zapojení CT $\mathrm{v}$ neinformatických předmětech. Cílem přitom není udělat z žáků informatiky. Začneme několika doporučeními.

Prvním krokem k zařazení CT je položit si otázku: Jak lze probírané problémy efektivně řešit $\mathrm{v}$ dnešních podmínkách? Tradiční metody práce (hledání v papírovém slovní$\mathrm{ku}$, ruční řešení soustavy rovnic) samozřejmě neztrácí svůj didaktický význam. Žáci se ale musí seznámit i s tím, jak se daná činnost řeší ve skutečnosti, včetně toho, jaké další problémy z daného oboru lze díky informatice řešit (např. 
cílené navrhování makromolekul s žádanými vlastnostmi). Nejčastější použití CT mimo informatické předměty souvisí s pokročilou analýzou rozsáhlých dat, modelováním a simulacemi. Simulace jsou koneckonců vedle experimentů a teorie považovány za třetí pilír vědy [22]. Další informace k zapojování CT do výuky nalezneme $\mathrm{v}$ [23].

Rozvoj CT v neinformatických předmětech není na jejich úkor, naopak. Informatický pohled na dané téma žákům umožní hlubší pochopení souvislostí. Např. v biologii se tak nutně budou ptát, jak přesně spolu souvisí genetická informace $\mathrm{v}$ buňce a částečná informace v pohlavní buňce: jak jsou vybrány ty části? Podobně, od rodičủ sice dědíme geny, přitom nám ale předávají celé chromozomy, kterých je o mnoho řádů méně. Jak je to tedy s výslednou rozmanitostí? Různé úrovně abstrakce si přeci musí odpovídat. Zapojení CT tedy umožňuje také odhalování miskonceptů. Dalším nástrojem jejich odhalování je samostatná formulace probíraných postupů jako algoritmů (např. hledání kořenů kvadratické rovnice formou vývojového diagramu).

Bez ohledu na předchozí je pak důvodem pro rozvoj $\mathrm{CT}$ v neinformatických předmětech fakt, že se CT, tedy aspoň za zdmi škol, stalo jejich přirozenou součástí. Chce-li tedy žák oboru plně porozumět, popř. se jím zabývat ve svém dalším životě, neobejde se bez příslušných souvislostí (např. jazykové korpusy a strojové překlady, geografické informační systémy, simulace a modelování, sběr a vytěžování velkých dat atp.).

Konkrétní př́klady uvedeme záměrně méně obvyklé, abychom tak naznačili šíríi dostupných možností. Začněme v oblasti Člověk a svět práce. Rozvíjet CT lze snahou o optimalizaci pracovních postupů. Jak nejlépe zorganizovat obsah ledničky? Jak nejlépe zorganizovat vybavení kuchyně? Co znamená ,jak nejlépe“? Jde o ušetřený čas při práci, snadný úklid, co nejvíce ušetřeného prostoru? Každý může mít svoje priority a $\mathrm{z}$ nich vyplyne optimální organizace. Přínos spočívá $\mathrm{v}$ uvědomělém a promyšleném rozhodování: „přestože jsem od maminky zvyklý jinak, uložím mléko do dveří ledničky, protože je tam snáz dostupné, takže ušetřím čas." U pracovních postupů (recepty, konstrukční návody) můžeme nechat žáky uvažovat nad závislostmi jednotlivých úkonů. Které $\mathrm{z}$ nich je nutno dělat $\mathrm{v}$ daném pořadí? Které lze dělat zároveň? Kolik kamarádů mi může pomoci? Jak můžeme být nejrychleji hotovi? $\mathrm{Na}$ tyto prrirozené otázky následně hladce naváže látka informatiky, která umožní žákům získané intuitivní poznatky strukturovat, zobecnit a dát do souvislostí. 
Ve výtvarné výchově lze pracovat s fraktálními ornamenty - at' už ručně, nebo s pomocí technologií [24]. Kromě toho, že jsou výsledky samy o sobě esteticky hodnotné, přímá zkušenost žáků s rekurzí jim nenásilně zprostředkuje několik zásadních poznatků. Dá překvapivě hodně práce (resp. počítači dlouho trvá) dostat se byt' do malé hloubky. Složité útvary lze někdy překvapivě jednoduše popsat. Tím pádem ovšem není jednoduše vidět, $\mathrm{k}$ jakému výsledku daný popis vede.

$\mathrm{V}$ matematice se lze věnovat problémovým úlohám a př́pravě na jejich informatické řešení. Zakreslení stavového prostoru úlohy o převozníkovi hlídajícím vlka, kozu a zelí či úloh o přelévání žákům ukáže jiný pohled na řešení problémů. Aniž by bylo nutno hned probrat algoritmy procházení grafư, žáci zjistí, že ač se to zprvu nezdá, lze postupovat systematicky. Talent pak není podmínkou úspěchu při řešení, žáci poznávají, že k němu vede i správně nasměrovaná a zorganizovaná píle.

Dalším netradičním příkladem budiž řešení Grelling-Nelsonova paradoxu [25], který lze pojmout jako jazykové cvičení. Přídavná jména jako „libozvučné“, „konečné“ či ,pětislabičné“ můžeme považovat za samopopisná, tedy popisujicí sama sebe. Adjektiva ,jednoslabičné“ či ,,anglické“ samopopisná nejsou. Zdá se, že lze o každém adjektivu říci, jestli samopopisné, či nikoliv. Jaké je tedy „samopopisné“? Jedná se o selfreferenční paradox podobný např. paradoxu lháře. Paradox lháře patří sice na první pohled do logiky a ne do informatiky, ale jen dokud si neuvědomíme, že je informatika na logice postavena.

Kromě toho hraje paradox lháře důležitou úlohu při zkoumání problému zastaveni ${ }^{3}$ a tím tedy i hledání odpovědi na otázku, co vypočítat lze, a co už nikoliv. To je klíčové téma informatiky a pochopitelně i CT. Můžeme odhadovat, že žáci, kteří se již nad paradoxem zamýšleli, snáze porozumí i pozdějším úvahám, již přímo souvisejícím s problémem zastavení. Proto uvedený paradox řadíme mezi př́iklady rozvoje CT.

Podobně důležitý je $\mathrm{v}$ informatice fakt, že algoritmy s exponenciální časovou složitostí jsou v praxi často $\mathrm{k}$ ničemu. Tomu lze ovšem mnohem snáz porozumět na základě předchozí zkušenosti s exponenciálním vývojem a jeho rychlostí (i mimo informatiku).

Množství dalších námětů pro různé předměty a různé věkové skupiny uvádí [10, 26, 27]. Jako př́klady zde zmíníme modelování

3 Self-referenci podle vzoru paradoxu lháře využíváme ke konstrukci stroje, který ukáže, že předpoklad řešitelnosti problému zastavení vede ke sporu. 
přepisu DNA na proteiny, zaplňování orbitalů, radioaktivního rozpadu, letu balistických střel, zkoumání (hypotetické či skutečné) černé skř́iňky, kódování a šifrování, skupinovou tvorbu príběhu $\mathrm{s}$ následným hledáním a odstraňováním logických nesrovnalostí, odvození gramatických pravidel (např. z ukázkových dat) a jejich algoritmickou formulaci.

\section{Závěr}

Jak nám tedy může koncept CT prospět? Ve výuce informatiky nám pomáhá oprostit se od zaměření na konkrétní technologie a jejich užívání. Může posloužit jako rámec pro strukturování a formulování pokročilejších kognitivních vzdělávacích cílů.

Dále CT osvětluje význam informatiky pro ostatní obory, souvislosti prredmětů mezi sebou i s životem mimo školu. Dává tak vyučujícím různých predmětů půdorys pro diskuse a spolupráci. Za hlavní důvod pro zapojení CT do jejich výuky (kromě aktualizace látky) lze prítom považovat snahu o prohloubení porozumění probíraným jevům.

Cílem rozvoje CT na školách není výchova populace programátorů. $\mathrm{CT}$ je $\mathrm{v}$ různé míře užitečné pro každého. Umožňuje řešit problémy, jejichž rozsah a složitost je překážkou řešení jiným způsobem. Navíc právě otevřené a komplexní problémy jsou ty, které nedovedeme řšit prrímočaře a mechanicky, a je tedy nutno uplatnit tvůrčí lidskou mysl. Zároveň jsou to právě ty problémy, kterým se ve výuce mnozí žáci (někdy spolu s učiteli) rádi vyhnou.

Považujeme-li za základní dovednost počítání, měli bychom s ohledem na vývoj lidského poznání uvažovat o přijetí CT mezi základní dovednosti. Lze na něj nahlížet jako na rozšíření počítání ve svém nově objeveném významu, totiž zpracování informací.

CT umožňuje racionální rozhodování i v obtížnějších situacích a pomáhá dopady našich rozhodnutí předvídat. Znásobuje možnosti každého člověka ve světě, ve kterém roste význam informací a kde je výpočetní technika všudypř́tomná. Pomáhá přitom technickému vývoji, jeho důsledkům, rychlosti, i principiálním limitům porozumět. To se může ukázat jako zásadní mj. pro správné kariérní rozhodnutí [28].

Schopnost automatizovat řešení problémů člověka $\mathrm{v}$ konečném důsledku osvobozuje, umožňuje mu totiž zacházet se svým časem podle svého prrání.

Ve světle v článku uvedených informací proto pokládáme otázku: jak si přeložíme computational thinking? 
10 Literatura

[1] PAPERT, Seymour a Idit HAREL. Situating Constructionism. In: Constructionism. Ablex Publishing Corporation, 1991, p. 193206.

[2] BLAHO, Andrej a Ivan KALAŠ. Imagine Logo - programování pro děti. Brno: Computer Press, 2006.

[3] PAPERT, Seymour. An Exploration in the Space of Mathematics Educations. International Journal of Computers for Mathematical Learning. 1996, Springer, vol. 1, no. 1, pp. 95-123.

[4] WING, Jeannette M. Computational thinking. Communications of the ACM. 2006, vol. 49, no. 3, pp. 33-35. ISSN 00010782.

[5] WING, Jeannette M. Computational Thinking: What and Why? [online]. 2010 [cit. 2013-10-28]. Dostupné z:

https://www.cs.cmu.edu/ Comp Think/papers/TheLinkWing.pdf

[6] CUNY, Jan, Larry SNYDER a Jeannette M. WING. Demystifying Computational Thinking for Non-Computer Scientists. 2010 [7] Operational Definition of Computational Thinking for K-12 Education [online]. B. m.: International Society for Technology in Education (ISTE) a Computer Science
Teachers Association (CSTA). 2011. Dostupné z:

http://csta.acm.org/Curriculum/sub/ CurrFiles/CompThinkingFlyer.pdf

[8] STEPHENSON, Chris a Valerie BARR. Defining Computational Thinking for K-12. CSTA Voice. 2011, vol. 7, no. 2, pp. 3-4.

[9] FURBER, Steve. Shut down or restart? The way forward for computing in UK schools [online]. London: The Royal Society, 2012. Dostupné z:

http://royalsociety.org/uploadedFile s/Royal_Society_Content/educatio n/policy/computing-inschools/2012-01-12-Computing-inSchools.pdf

[10] GOOGLE, Inc. What is CT? Exploring Computational Thinking [online]. [cit. 2013-10-28]. Dostupné z:

http://www.google.com/edu/compu tational-thinking/what-is-ct.html

[11] CURZON, Paul, Peter BLACK a Jonathan MCOWAN. What is Computational Thinking? Computer Science for Fun [online]. [cit. 2013-10-28]. Dostupné z: http://www.cs4fn.org/computationa lthinking/index.php

[12] BELZ, Horst a Marco SIEGRIST. Klíčové kompetence a jejich rozvijení. Praha: Portál, 2001. 
[13] KOLEKTIV. Gramotnosti ve vzdělávání [online]. Praha: Výzkumný ústav pedagogický v Praze, 2010. ISBN 9788087000410. Dostupné z:

http://www.nuv.cz/uploads/Publika ce/vup/Gramotnosti_ve_vzdelavani 11.pdf

[14] NAVLAKHA, Saket a Ziv BAR-JOSEPH. Algorithms in nature: the convergence of systems biology and computational thinking. Molecular Systems Biology. 2011, vol. 7, no. 546.

[15] DIBLÍKOVÁ, Lucie. Pták roku 2011: zapojení veřejnosti při analýze regionální variability ptačího zре̌vu. B. m., 2013. Univerzita Karlova v Praze.

[16] ABRAHAM, David J, Avrim BLUM a Tuomas SANDHOLM. Clearing Algorithms for Barter Exchange Markets: Enabling Nationwide Kidney Exchanges. In: Proceedings of the 8th ACM conference on Electronic commerce. New York, NY, USA: ACM, 2007, p. 295-304.

[17] JARUSEK, Petr a Radek PELÁNEK. A web-based problem solving tool for introductory computer science. In: Proceedings of the 17th ACM annual conference on Innovation and technology in computer science education -
ITiCSE '12. New York, New York, USA: ACM Press, 2012, p. 371. ISBN 9781450312462.

[18] KOŘENOVÁ, Martina. Figurková školička [online]. 2006 [cit. 2013-10-28]. Dostupné z: http://skolicka.figurka.net/

[19] LESSNER, Daniel a Jiř́ VANÍČEK. Bobřík učí informatiku. Matematika - fyzika - informatika [online]. Praha: Prometheus, 2013, vol. 22, no. 5, pp. 374-382. Dostupné z:

http://mfi.upol.cz/index.php/mfi/art icle/view/92/105

[20] BELL, Tim, Ian H WITTEN, Mike FELLOWS, Robyn ADAMS a Jane MCKENZIE. Computer Science Unplugged: An enrichment and extension programme for primary-aged children [online]. 2006. Dostupné z: http://csunplugged.org/ [21] BELL, Tim a Jack MORGAN. Computer Science Field Guide [online]. 2012 [cit. 2013-10-28]. Dostupné z:

http://www.cosc.canterbury.ac.nz/c sfieldguide/

[22] WILSON, Kenneth G. Grand challenges to computational science. Future Generation Computer Systems. 1989, vol. 5, no. 23, pp. 171-189 [cit. 2013-10-28]. ISSN 0167739X. 
[23] LEE, Irene, Fred MARTIN, Jill DENNER, Bob COULTER, Walter ALLAN, Jeri ERICKSON, Joyce MALYN-SMITH a Linda WERNER. Computational thinking for youth in practice. ACM Inroads. 2011, vol. 2, no. 1, p. 32. ISSN 21532184.

[24] SCHACHMAN, Toby. Alternative programming interfaces for alternative programmers. In: Proceedings of the ACM international symposium on New ideas, new paradigms, and reflections on programming and software - Onward! '12. New York, New York, USA: ACM Press, 2012, p. 1. ISBN 9781450315623.

[25] GRELLING, Kurt a Leonard NELSON. Bemerkungen zu den Paradoxien von Russell und BuraliForti. In: Abhandlungen der Fries'schen Schule II. 1907, p. 301-334.

[26] DWYER, Hilary, Bryce BOE, Charlotte HILL, Diana FRANKLIN a Danielle HARLOW. Computational Thinking for Physics: Programming Models of Physics Phenomenon in Elementary School. In: Physics Education Research Conference (PERC) Proceedings [online]. Portland, 2013. Dostupné z: http://www.compadre.org/PER/doc
ument/ServeFile.cfm?ID=13126\& DocID=3675

[27] PHILLIPS, Pat. Computational thinking - a problem solving tool for every classroom [online]. CSTA \& Microsoft Corporation, 2009. Dostupné z:

http://csta.acm.org/Resources/sub/ ResourceFiles/CompThinking.pdf [28] FREY, Carl Benedikt a Michael A OSBORNE. The future of employment: how susceptible are jobs to computerisation? [online]. 2013. Dostupné z:

http://www.futuretech.ox.ac.uk/site s/futuretech.ox.ac.uk/files/The_Fut ure_of_Employment_OMS_Worki ng_Paper_0.pdf

Mgr. Daniel Lessner

Kabinet software a výuky informatiky

Matematicko-fyzikální fakulta UK

Malostranské nám. 25

118 00, Praha 1, ČR

E-mail: lessner@ksvi.mff.cuni.cz www: ksvi.mff.cuni.cz/ lessner 